\title{
3-dimensional transoral carotid ultrasonography
}

\author{
萩原 悠太, 飯島 直樹, 小倉 英, 清水 高弘, 長谷川 泰弘
}

聖マリアンナ医科大学脳神経内科

\section{Three-dimensional transoral carotid ultrasonography}

\author{
Yuta HAGIWARA, Naoki IIJIMA, Hana OGURA, Takahiro SHIMIZU, Yasuhiro HASEGAWA
}

Department of Internal Medicine, Division of Neurology, St. Marianna University School of Medicine

\begin{abstract}
Transoral carotid ultrasonography (TOCU) is a powerful tool for evaluating internal carotid artery lesions located from the carotid bifurcation to the second cervical vertebra. In recent case reports, contrast-enhanced transoral carotid ultrasonography (CETOCU) and superb micro-vascular imaging (SMI) which are useful in endovascular therapy are emerging. Lately, three-dimensional (3D) and four-dimensional (4D) ultrasound have been widely used in angiology. We developed 3D-TOCU and used it in a healthy man to confirm the utility of the $3 \mathrm{D}$ technique. Mutual conversion to the long axis from the short axis is possible based on an image of a vessel using multiplanar reconstruction (MPR) in 3D-TOCU. By operating the ultrasound machine, a novice examiner can obtain an adequate image in TOCU. TOCU performed with single sweep mode can produce the intraluminal vessel image from proximal to distal on the short axis, which is not possible with conventional TOCU. 3D-TOCU is expected to be clinically useful.
\end{abstract}

Keywords: transoral carotid ultrasonography, 3-dimensional ultrasound, carotid ultrasound

(Received October 3, 2019; Accepted November 7, 2019)

\section{はじめに}

通常の頸動脈超音波では観察不能な高位の内頸動脈を 評価する経口腔頸動脈超音波（transoral carotid ultrasonography：TOCU $)^{1-4)}$ は, 造影経口腔頸動脈超音波 (contrast-enhanced transoral carotid ultrasonography : CETOCU $)^{5-9)}$ や superb microvascular imaging $(\mathrm{SMI})^{10-12)}$ を用いた TOCU (SMI-TOCU) などの新た な技術が開発され，血管領域における有用性を高めてい る。ささらに近年は血管領域以外に抢いても，口腔内不随 意運動を観察する transoral M-mode ultrasonography $(\mathrm{TOMU})^{13)}$ ，耳鼻咽喉科領域で使用する transoral pharyngeal ultrasonography $(\mathrm{TOPU})^{14)}$ が報告され, 経口腔 超音波としての可能性が広がりつつある.

$3 \mathrm{D}$ 機能を使用した超音波は, 心臟領域を筆頭に多く の領域で広く使用されており, 頸動脈超音波においても プラーク表面・潰瘍の形態評価や，プラークの容量計測
に有用であることが報告されている ${ }^{15)}$ ，TOCU は血管 病変の形態評価を得意とした超音波であり，3D 機能を 使用することで病変が多角的に観察され，さらに有益な 情報を得られる可能性がある，今回，血管領域における 新技術として 3D 機能を使用した TOCU (3-dimensional transoral carotid ultrasonography : 3D-TOCU) を健常例 に施行したので，現時点で想定される有用性について報 告する.

本報告に際し，被検者からは文書にて同意を得た．

症例

32 歳男性. 身長 $170 \mathrm{~cm}$, 体重 $62 \mathrm{~kg}$, 生来健康.

\section{超音波}

超音波装置：Aplio a550（キヤノンメディカルシステム ズ, 栃木).

プローブ : PVT-681MVL（キヤノンメディカルシステ

\section{Reprint request}

萩原悠太：７216-8511 神奈川県川崎市宮前区菅生 2-16-1 聖マリアンナ医科大学脳神経内科

Yuta HAGIWARA: Department of Neurology, St. Marianna University School of Medicine, Sugao, Miyamae-ku, Kawasaki, Kanagawa 216-8511, Japan

E-mail: y2hagiwara@marianna-u.ac.jp, Tel: +81-44-977-8111, Fax: +81-44-976-8516 

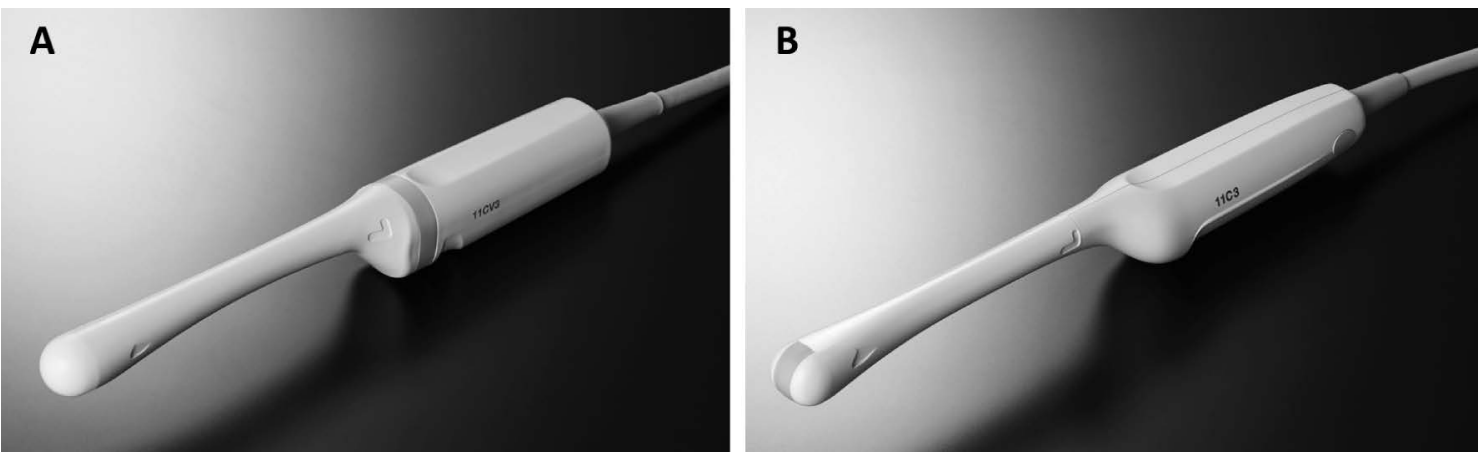

Fig.1 Transvaginal probe (Canon Medical Co., Tochigi, Japan)

A: PVT-681MVL (4D probe)

B: PVT-781VTE (conventional probe)

There are no significant differences in the shape and size of probes. The tip of $4 \mathrm{D}$ probe is more spherical than the conventional probe.

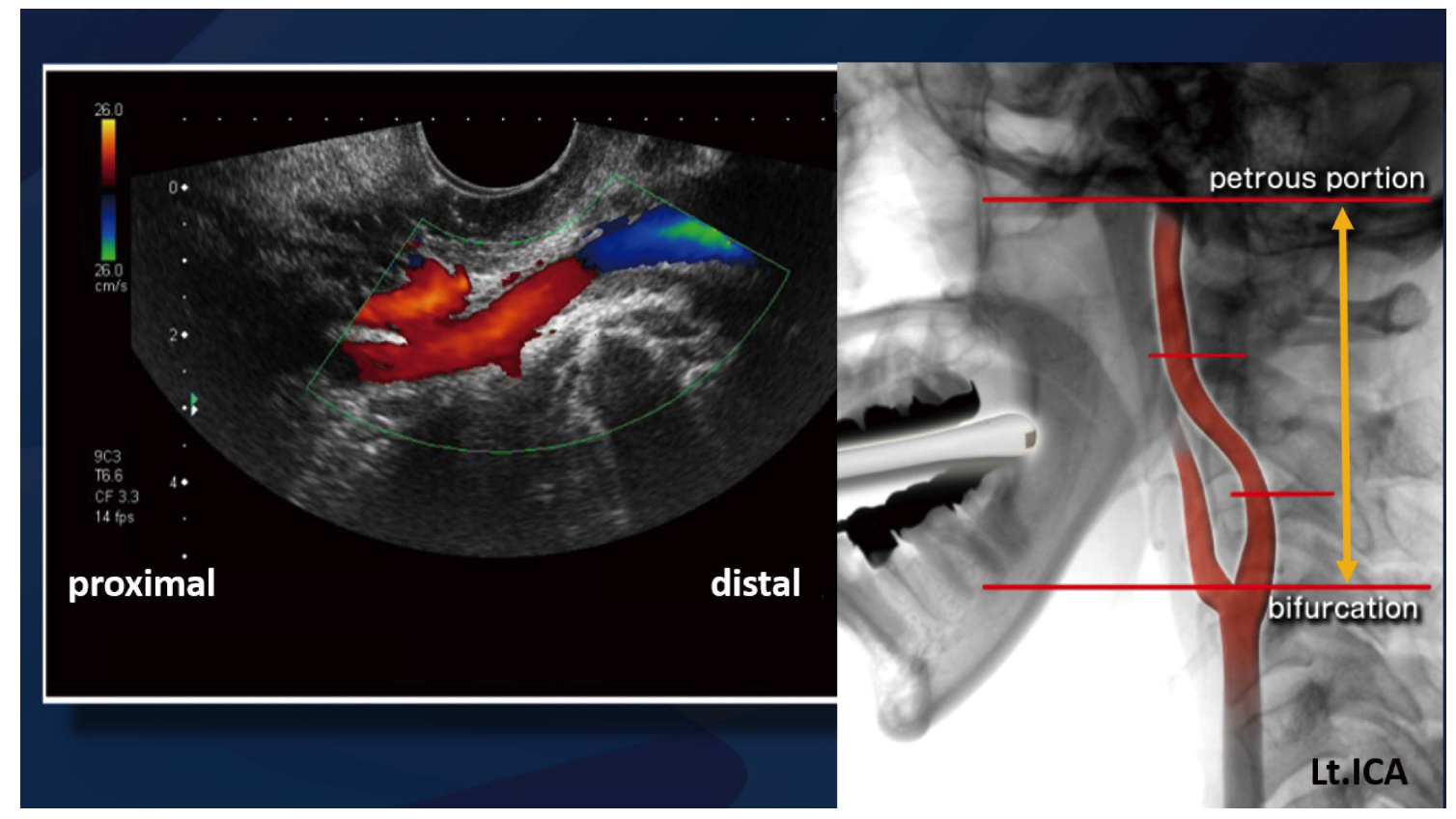

Fig. 2 Conventional TOCU

The right image is schematic image of carotid angiogram, and double headed yellow arrow indicates the examination range of TOCU. The left image is long axis view of TOCU with color-Doppler.

ムズ, 栃木). 3D, 4D 機能に互換性のある本プローブは, 形状と大きさは従来の経腟（体腔）プローブと大きな差 異はない. 先端は従来のものに比べ, より球状に近くなっ ている (Fig.1).

Single Sweep モード：振動子を機械的に摇動制御でき る 4D プローブを使用し，1 方向に低速で一度だけ摇動 させ，高密度な 3 次元デー夕を取得し，詳細な 3 次元 画像の構成を行う.

MPR (multi planar reconstruction) : Single Sweep モードで収集したボリュームデー夕は任意の断面を表示 することが可能である。このデー夕をもとに，MPR表 示では, 走査方向を $\mathrm{A}$ 面, 摇動方向を $\mathrm{B}$ 面, 体腔内構 造物の表面に平行な面を C 面というように，定義した 断面を同時に表示することが可能であり，病変とその周 囲について多面的に観察することが可能となる。 経口腔頸動脈超音波（transoral carotid ultrasonography：TOCU)：TOCU は通常の頸動脈超音波の装置 設定で経腟プローブを用いて行う。被検者は仰臥位とす る，通常は，咽頭麻酔は使用せずに検查可能である。プ ローブ先端に検査用ゼリーをのせ，医療機器用コンドー ムをカバーとして用いる．観察したい頸動脈側の扁桃へ 向かい，対側口角から口腔内を横断するようにプローブ を挿入すると咽頭反射が少ない，画面右側を頭側，左側 を心側として描出する. TOCUの模式図を Fig.2に示す. 黄色矢印の部分が TOCU の検査範囲である。この範囲 の中部より遠位は，通常の頸動脈超音波では観察できな い.

短軸像および長軸像の構築：描出された血管長軸像か ら, Single Sweep モード, MPRを使用し, 装置側操作 で短軸像を構築できる（Fig.3）。描出された血管短軸像 


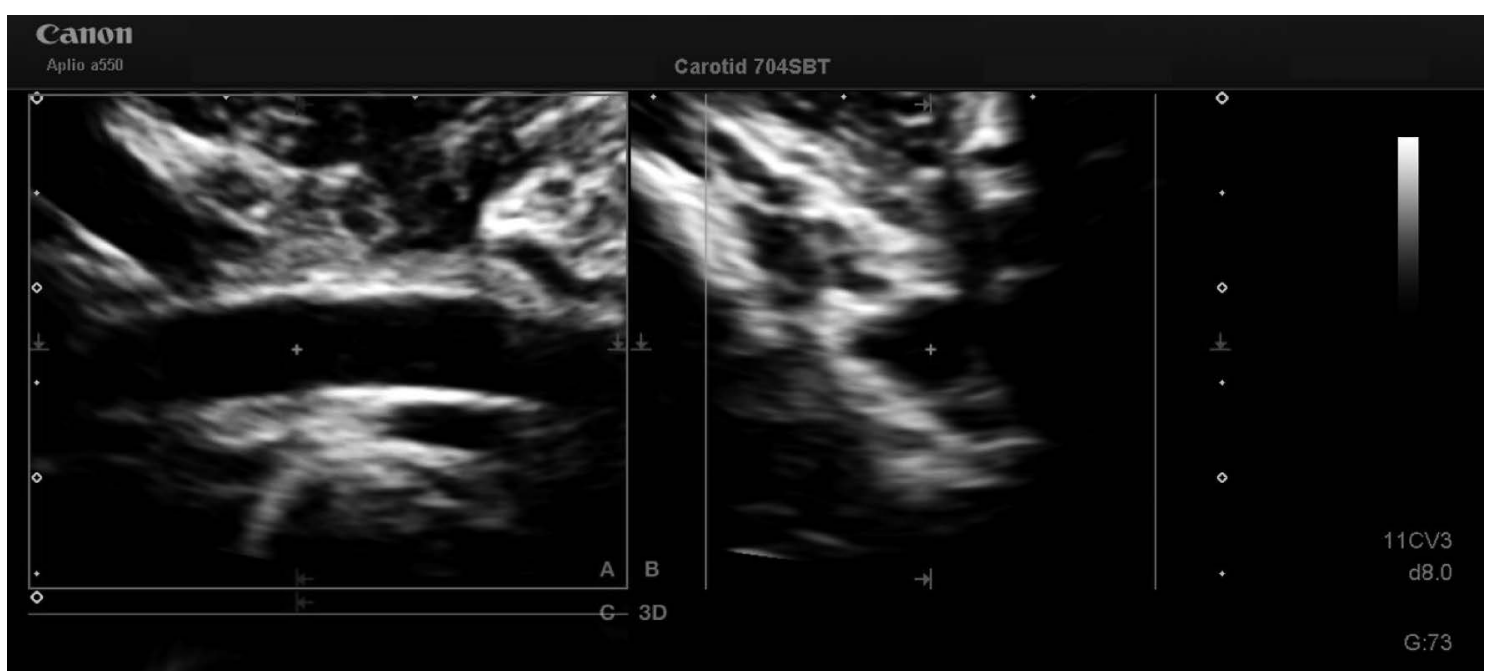

Fig.3 3D-TOCU long axis

The distal side is the right side of the image, and the proximal side is the left side of the image. The left image is the long axis view of the right internal carotid artery (ICA) demonstrated by the examiner, and the right image is the short axis view produced by multiplanar reconstruction (MPR). Long axis view and short axis view are demonstrated synchronously in same display screen.

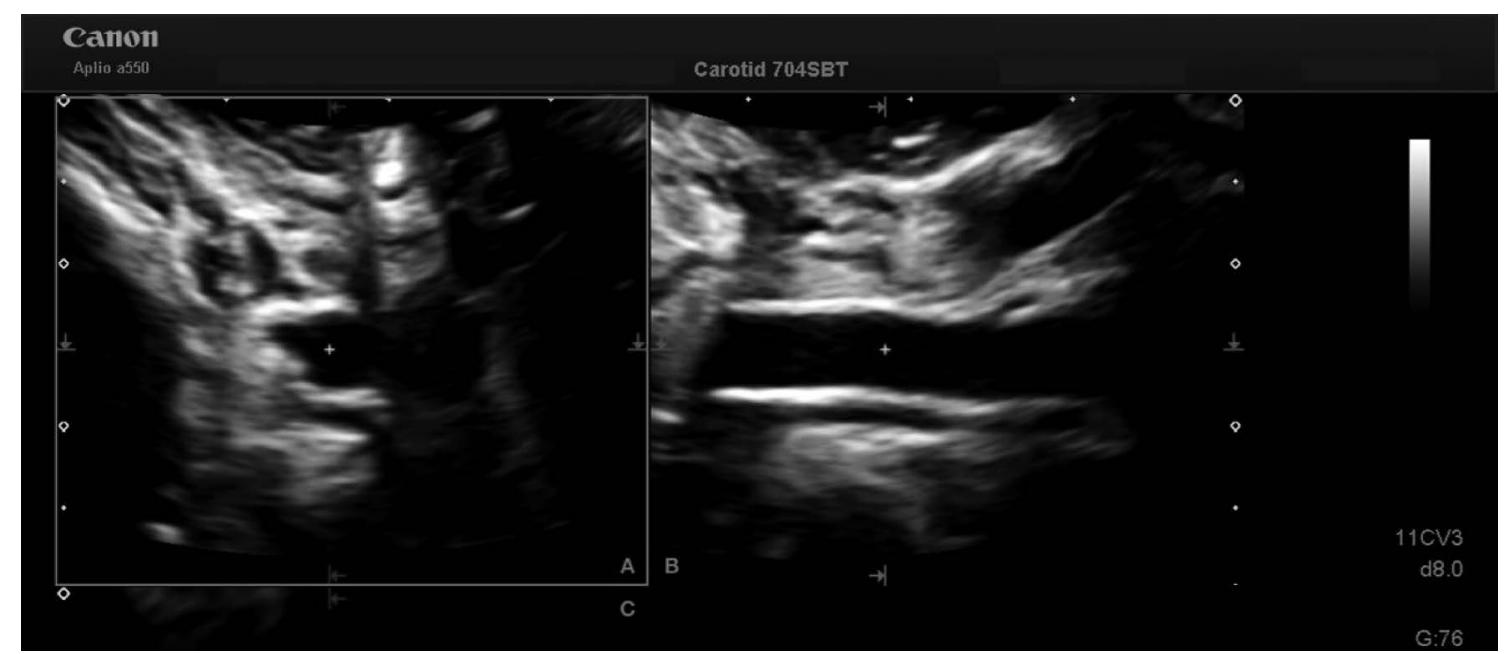

Fig.4 3D-TOCU short axis

The left image is the short axis view of the ICA demonstrated by the examiner, and the right image is the long axis view produced by MPR.

からは，同様の方法で長軸像を構築できる（Fig.4）。同 一の画面内に長軸像と短軸像が同期して提示されること も3D-TOCUの特徴である.MPRを使用する場合, 3D 像を構成するための Single Sweep モードによる基線 は水平方向に移動するので，長軸像ではなるべく血管自 体を水平になるように描出するのが望ましい. Fig.5の 1 から 8 に向かってスキャンされ，それぞれの位置での 断面が自動で構築される。動画では，これらの静止画を 連続して観察することができる。

考察

TOCU は長軸で評価することが基本であるが，短軸 での評価を要する場合もある。たとえば，TOCUがきわ めて有用となる頭蓋外内頸動脈解離では double lumen
は短軸像で確認しやすい. intimal flap が生じている方 向が， 12 時〜 6 時方向に近ければ近いほど，短軸像の 情報が大きい。しかし，これまでTOCUでの短軸像は， ある一点での評価はプローブを時計軸方向に回転させる ことで描出可能であるが，短軸像で近位から遠位に血管 を追っていくような動きは困難であった。これは，経胵 プローブの形状が純粋な球体ではないため，長軸像と短 軸像ではプローブ先端が接地する面積が変わることに起 因している. 口腔内というきわめて制限のある空間では, 「血管を追う」という操作が難しい

Single Sweep モードは，振動子を機械的に摇動制御可 能な $4 \mathrm{D}$ プローブを使用し，1 方向に低速で一度だけ摇 動させて高密度な 3 次元デー夕を取得することで, 詳 細な 3 次元画像の構成を可能にした技術である。ある 


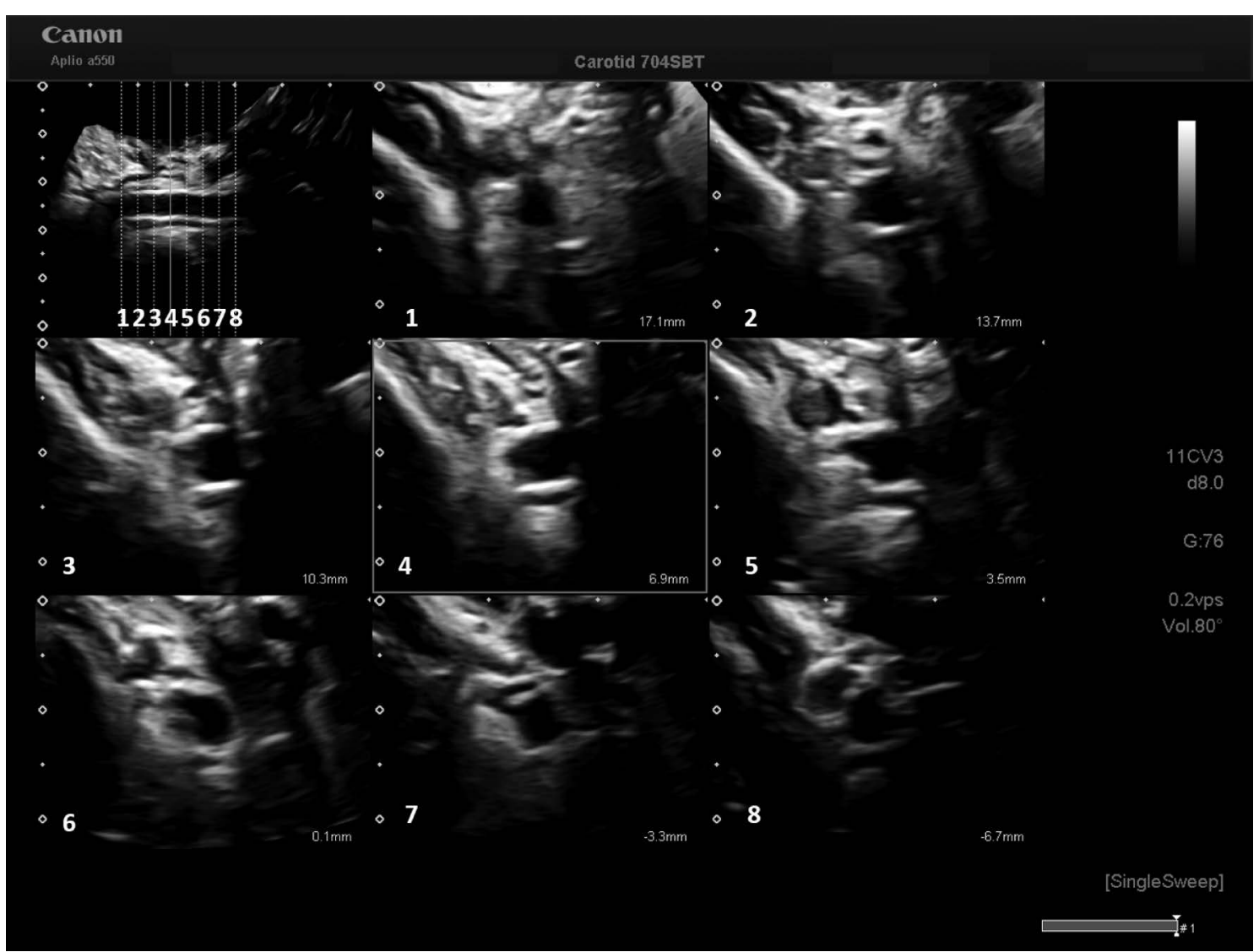

Fig.5 3D-TOCU with MPR

The short axis image is constructed by the information of the long axis view of the right ICA using MPR.

一点で血管が確認できれば，あとは装置側の操作で血管 を追うことが可能である，TOCUに扔いては，短軸で の近位から遠位への内頸動脈描出はこの機能を利用しな ければ得ることが難しく，この点は 3D-TOCUの大き な特性と考えられる。頸動脈留置術後のステント内 protrusion や，ステント内再狭窄の評価に関しては，血管 内超音波（intravascular ultrasound：IVUS）に近い画像 が得られるであろう。

Single Sweep モードで収集したボリュームデータは任 意の断面を表示することが可能であり，MPR 表示を使 用すると, 走查方向を A 面, 摇動方向を B 面, 対象物 を下面から見たC 面と，定義した断面を同時に表示す ることが可能である。 今回の提示症例では C 面は提示 していないが，このA面，B面の表示は TOCU では長 軸と短軸の関係であり，Single Sweep モード，MPR表 示を使用することで，初心者でも容易に適切な画像を得 ることが可能である，また，同一画面に長軸像と短軸像 が同期して描出されるので, 確実に同部分の長軸像と短 軸像を得ることができる。

TOCU は操作が複雑な超音波であり，習得できるま でに一定の訓練を要する。プローブ先端は球面に近く, 口腔内でプローブを接地させる部分も曲面である。 その ためプローブは回転的な操作が必要となるが，口腔内は
狭くプローブの可動域に制限がある。この点が体表での リニアプローブの操作と大きく異なっており，長軸と短 軸の切り替えが容易ではない。 ハンズオントレーニング は，検者の育成に最も有用であるが，多くの機会を作る のは難しい，検者がまだ操作に慣れていない段階では, 積極的に3D 機能を使用し，機械側の操作で適切な画像 を得ることを試みるのも，TOCU の汎用性を高めるに は有効な手段と考えられる。

3D-TOCUは「短軸像での近位から遠位の連続した 観察」「装置側操作による長軸・短軸の切り替えと適切 な画像の取得」の点では有用であるが，Fig.3を見るか ぎり現時点では3D-TOCUによる解像度は低く, 詳細 な評価までは難しい印象である，今後さらに改良を進め ることで，この点は解決されてくるであろう．

今回の検査では血管の $3 \mathrm{D}$ 構築も試みたが，画質が粗 いため適切な構築ができず提示には至らなかった，病変 の多角的な観察には立体構築像を得る必要があり, 今後, 構築が可能になるよう技術を発展させていきたい.

TOCU は, CETOCU, SMI-TOCU, 3D-TOCU と 進化を続けてきた。経腟プローブやSMI といった既存 のッールを用いながら発展してきた検査であるが，今後 はTOCU 自体に照準を合わせた開発が進むことが望ま れる 
利益相反 : 著者全員が，本論文に関わる研究に関して 利益相反はない.

\section{-文献}

1) Yasaka $M$, Kimura $K$, Otsubo $R$, et al.: Transoral carotid ultrasonography. Stroke 1998: 29: 1383-1388.

2）萩原悠太, 清水高弘, 田中成明, 他：症候性頭蓋外内頸動脈 解離後に新たな対側内頸動脈の無症候性解離の出現を確認し 得た 1 例：経口腔頸部血管超音波検査法（TOCU）による経 時的観察の意義. Neurosonology 2015; 28: 63-66.

3）萩原悠太，小野寺英孝，内田将司，他：巨大頭蓋外感染性内 頸動脈瘤に対する内頸動脈母血管コイル閉塞術と排膿穿刺術 に打ける経口腔頸動脈超音波検査（transoral carotid ultrasonography）の有用性. 脳卒中 2017; 39: 215-219.

4) 萩原悠太, 吉江智秀, 徳山承明, 他 : 頭蓋外内頸動脈解離に 対する頸動脈ステント留置術前後の評価に経口腔頸動脈超音 波検查 (transoral carotid ultrasonography) が有用であった 1 例. Neurosonology 2016; 29: 185-190.

5）清水高弘, 伊藤英道, 田中雄一郎，他：造影経口腔頸部血管 超音波 (CETOCU) による頭蓋外内頸動脈解離の評価 Neurosonology 2016; 29: 1-3.

6) Hagiwara Y, Yoshie T, Shimizu T, et al.: A case in which contrast-enhanced transoral carotid ultrasonography was useful for pre- and post-procedural evaluation in carotid artery stenting. J Med Ultrason 2017; 44: 207-210.

7) Hagiwara Y, Yoshie T, Shimizu T, et al.: Contrast-enhanced transoral carotid ultrasonography for the evaluation of plaque protrusion after carotid artery stenting. J Clin Ultrasound 2018; 46: 598-601.

8) Hagiwara $Y$, Yoshie $T$, Shimizu T, et al.: Contrast-enhanced transoral carotid ultrasonography for the evaluation of a long stenotic lesion in the internal carotid artery. Clin Case Rep 2016; 4: 1215-1216.

9) Hagiwara Y, Shimizu T, Hasegawa Y: Contrast-enhanced transoral carotid ultrasonography for the diagnosis and followup of extracranial internal carotid artery dissection: A case report. J Clin Ultrasound 2018; 46: 368-371.

10) Hagiwara $Y$, Shimizu $T$, Hoshino $M$, et al.: The utility of superb-microvascular imaging for evaluating the full length of carotid artery stents. J Clin Ultrasound 2019; 47: 239-242.

11）萩原悠太, 小倉英, 清水高弘, 他： superb microvascular imagingを用いた経口腔頸動脈超音波検査. Neurosonology 2018; 31: 13-17.

12）小倉英，萩原悠太，清水高弘，他：頭蓋外内頸動脈解離に対 する頸動脈ステント留置術後の評価にsuperb microvascular imaging を用いた経口腔頸動脈超音波検査が有用であった 1 例. Neurosonology 2019; 32:57-61.

13）萩原悠太，柳澤俊之，清水高弘，他：Mモードを用いた経口 腔超音波検査による舌不随意運動の評価. Neurosonology 2018; 31, 134-137.

14) Hagiwara $Y$, Araga $T$, Saito $Y$, et al.: Utility of transoral pharyngeal ultrasonography for puncture drainage of peritonsillar abscess. Clin Case Rep 2019; 7: 839-840.

15) Saito K, Yamagami H: Ultrasound diagnosis of carotid plaques. JNET 2018; 12: 581-591. 